\title{
Sampling and Mechanical Testing of Backfill in Large Mined- Out Area
}

\author{
D. Q. Deng $\mathbb{D}^{1,2}$ N. Jiang, ${ }^{3}$ and Y. Duan $\mathbb{D}^{2}$ \\ ${ }^{1}$ School of Civil Engineering and Mechanics, Xiangtan University, Xiangtan, Hunan 411105, China \\ ${ }^{2}$ Institute of Mining Engineering, Guizhou Institute of Technology, Guiyang, Guizhou 550003, China \\ ${ }^{3}$ Caolou Iron Mine, Jin'an Mining Co., Ltd., Liu'an, Anhui 237426, China \\ Correspondence should be addressed to D. Q. Deng; ustbb20070025@126.com and Y. Duan; 417316026@qq.com
}

Received 19 November 2020; Revised 30 November 2020; Accepted 2 January 2021; Published 30 January 2021

Academic Editor: Yanlin Zhao

Copyright @ 2021 D. Q. Deng et al. This is an open access article distributed under the Creative Commons Attribution License, which permits unrestricted use, distribution, and reproduction in any medium, provided the original work is properly cited.

To investigate the physicomechanical properties of stope backfill and to explore the mining conditions for an adjacent pillar, four boreholes, namely, GZK1, GZK2, GZK3, and GZK4, were constructed for taking the backfill core in the test stope. During borehole sampling, it is found that the strength of backfill is usually lower than that of the rock and ordinary concrete, and its resistance to tensile and compressive loads is limited. Therefore, the drilling speed should not be too fast, and a small amount of water is needed to continue drilling smoothly. For backfill with high strength, the sampling process is relatively smooth, and the backfill samples are relatively complete. GZK1 is located on the upper part of the stope near the footwall of the orebody, and the test results show that the backfill quality of this part is poor; thus, a complete backfill core cannot be obtained. GZK2 is located at the bottom of the stope close to the footwall of the orebody, GZK3 is located at the bottom of the stope close to the hanging wall of the orebody, and GZK4 is located at the top of the stope close to the hanging wall of the orebody. The average compressive strength and average tensile strength of the backfill samples obtained from the three boreholes, namely, GZK2, GZK3, and GZK4, are 2.928 to $3.583 \mathrm{MPa}$ and 0.328 to $0.523 \mathrm{MPa}$, respectively, indicating that the backfill near the upper part and bottom close to the hanging wall of the orebody is good, while the backfill near the upper part close to the footwall of the orebody is poor. Special attention should be paid to the backfill with the range of GZK1 in the future second-step pillar mining process, and the sublevel method can be adopted to ensure the safety of the mining process. The backfill samples in the large goaf of No.17 room were obtained by geological drilling. Segregation occurred in the upper part of the No.17 room near the area of the footwall. The concentration and flow rate of the filling slurry were reasonably adjusted and controlled with the improvement of backfill quality. Therefore, the backfill strength of the No.17 room is generally good, which can meet the requirements of pillar mining, and also creates a good condition for the resource utilization of waste tailings of Caolou Iron Mine.

\section{Introduction}

In the mining process of valuable minerals, various solid wastes are discharged simultaneously. For instance, tailing with no recovery value is generally discharged and stored in tailing pond in mines. For mines operating with the backfill mining method, tailing is partially used for underground goaf filling. As a green, environmental, safe, and sustainable mining method, two-step mining is usually involved in backfill mining [1-5]. Due to the many advantages of the technology of filling goaf, when the ore is being mined, the stress of the original rock can be redistributed, and the stress of the rock is relatively complex at this stage, in order to prepare for it [6-11].

In some deep mines at home and abroad, the researchers have compared the sound propagation properties of the surface and underground rock samples and summarized the law of the sound propagation, and in view of the problem of the maintenance of the rock in the mined-out area of the ocean mining, some environmental protection measures affecting marine mining [12-14], rheological fracture behavior simulation of rock crack under the action of water pressure and far-field stress, and mechanical properties such as rock 


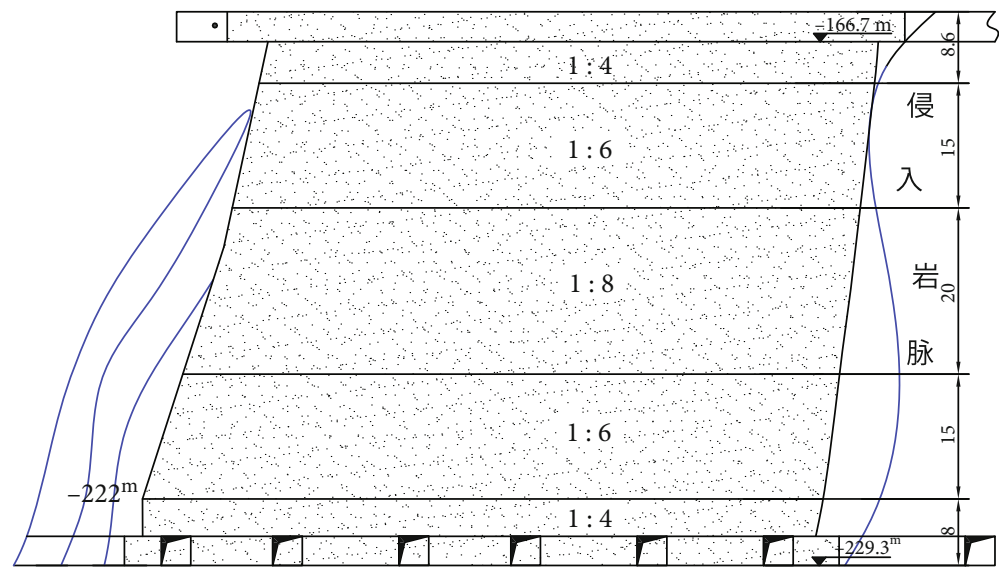

FIgURE 1: Cement tailing ratio in 17 \# room located at $-230 \mathrm{~m}$ level.

TABLE 1: Backfill drilling project list.

\begin{tabular}{lcccc}
\hline No. & Middle part & Location & Dip & Construction quantity \\
\hline GZK1 & -170 & Linked retaining wall at footwall & $-35^{\circ}$ & $17.2 \mathrm{~m}$ \\
GZK2 & -230 & Trench retaining wall at footwall & $35^{\circ}$ & $44.1 \mathrm{~m}$ \\
GZK3 & -230 & 5\# retaining wall & $45^{\circ}$ & $21.8 \mathrm{~m}$ \\
GZK4 & -170 & Linked retaining wall at hanging wall & $-45^{\circ}$ & $65.3 \mathrm{~m}$ \\
In total & - & - & - & $148.4 \mathrm{~m}$ \\
\hline
\end{tabular}

rheology are put forward; some laws obtained from the study can play a guiding role in the prevention of a rock burst. In the filling engineering of goaf, the mechanical properties of cemented backfill with high sulfur content tailings are discussed; it provides a good reference for preventing a rock burst and improving rock stress [15-18].

Due to the frequent occurrence of some disastrous safety accidents in the process of ore mining, a series of safety problems have arisen as a result, which often have a certain negative effect on production. For the maintenance of goaf and underground roadway, the conventional support methods such as long anchor cable, anchor rod, and shotcrete have played an important role, but for the huge mined-out area, the conventional support is no longer applicable at this time, so it is necessary to deal with the mined-out area permanently [19-22]. In recent years, great changes have taken place in the goaf filling technology, filling materials, and transportation methods, such as the continuous transportation technology of filling slurry and the development of new cementitious materials and filling aggregates; in order to make the filling process smooth, reduce the cost of filling, and reduce the collapse of the goaf rock, maintaining the safety of the goaf played a supporting role [23-27].

Sulfur-containing tail sand processing area, existence of sulfur-containing tail sand, constant sulfur-containing tail sand, and sulfide-containing easy-to-create one-sided environment. Comprehensive filling fee, comparatively favorable effect of obtaining a meeting in the area of the territory, and the use of sulfur-containing tail sand detoxifying at the same time [28]. Sulfur-containing tail sand operation Filling material, its filling sulfurization material binding performance, long-term indepth research, sulfur-containing tail sand cementation pack- ing body swelling performance, long-term strength, permeation performance, etc. Practicality of long-term mechanical performance research tool for sulfide-containing tail persimmon-forming cementation filler [29]. Inconsistent filling material and sand-like cementation possible Great inhomology, selection and comparison of suitable glue material, related research progress completed, one-series comparison test, analysis inconsistent glue material Performance shadow, analysis of conformity, suitable type of glue material [30]. The following were reviewed in this study: comparison, fine grain, cementation, dynamic performance, analysis of the results of research, expression of research results, comparison of mud-containing materials, the formation of cementation, the solidity of cementation, proof of reason, mud removal, filling performance equipment comparison of large-scale shadow, and removal of the part of extremely fine cementation tail sand opposite high packing material strength necessity [31].

And studies on technical problems of backfill mining are done by many scholars and researchers at home and abroad that provide a reference for solution of practical problems [32-35]. In a high-grade iron mine closely neighboring city, the cemented filling test with unclassified tailing was done to realize zero discharge of tailing as there is no tailing pond. Finally, tailings were used for background filling and realized wasteless mining [36]. In order to realize effective utilization of resources under the premise of safety in coal mines, the study and application of solid filling mining technology shown in relevant literatures are of popularization value in comprehensive mechanical mining and referential for similar projects $[33,37]$. The relevant study on the performance of cemented backfill using coal gangue as coarse aggregate was done in the view of coal gangue content and grain gradation 
[38]. The study on special underground part-mining tunnel filling is recorded in relevant documents and effectively applied [39]. As blasting vibration has an effect on the stability of backfill in two-step pillar mining, blast-hole arrangement and charge way are essential for keeping the integrity of the backfill. The study about this has been effective in practice $[40,41]$. As for the filling material, the mechanical properties of coal gangue were studied, and preparation as well as application of coal gangue was introduced in literatures [42]. Paste backfill starts earlier in developed countries, and many valuable experiences were gained in the selection and preparation of filling materials. The paste backfill technology applied in many mines in Canada could be referential for paste performance study [43].

Presently, the study on backfill quality with geological drilling and in situ sampling is rarely done in large goaf. In this study, the analysis of the filling project was done in Caolou Iron Mine, which is located in Huaibei Plain. The production scale of mine is $3,000,000 \mathrm{t} / \mathrm{a}$, which is covered by a stratum of quaternary with a thickness of $170 \mathrm{~m}$ and flow sand seams. The surface of the mining area is high-yield farmland; the mine is surrounded by villages and ponds. Considering surface protection, safe mining, high recovery rate of ores, and less tailing discharge, the backfill mining is applied in the mine. As the strength of backfill is necessary for two-step mining, the in situ geological drilling sampling is done. The standard samples made of backfill cores are used to test mechanical strength and analyze the quality of backfill to provide a reference for safe mining with a two-step pillar mining method.

\section{Engineering Background and Drilling}

2.1. Engineering Background. The drilling construction was done in $17 \# \mathrm{R}$ room at the middle part of the $-230 \mathrm{~m}$ level. The length of the stope is about $80 \mathrm{~m}$, height is about $60 \mathrm{~m}$, and width is about $15 \mathrm{~m}$. As a large goaf, it covers $73300 \mathrm{~m}^{3}$. As a firstly filled stope, the test and analysis of filling effect as well as backfill quality are needed to find out pillar stoping conditions at both sides of the room and will provide a reference for filling arrangement in the future. The filling plan for the test stope is finally set on the basis of geological and engineering conditions of goaf. The ratio of filling materials is shown in Figure 1.

2.2. Geological Drilling. Restricted by engineering conditions and geological drilling equipment, soft backfill in some regions led to failure in drilling and sampling at the first two boreholes in 17\#R. Based on technical demonstration, four new boreholes were determined, namely, GZK1, GZK2, GZK3, and GZK4. With geological drilling, backfill cores were drilled with a diameter of $\Phi 70 \mathrm{~mm}$, and drilling data are shown in Table 1.

\section{Geological Drilling Sampling and Mechanical Test}

3.1. Geological Drilling Sampling. The samples from in situ geological drilling are used to test the mechanical parameters of backfill. As Figures 2-5 show, no backfill core was drilled

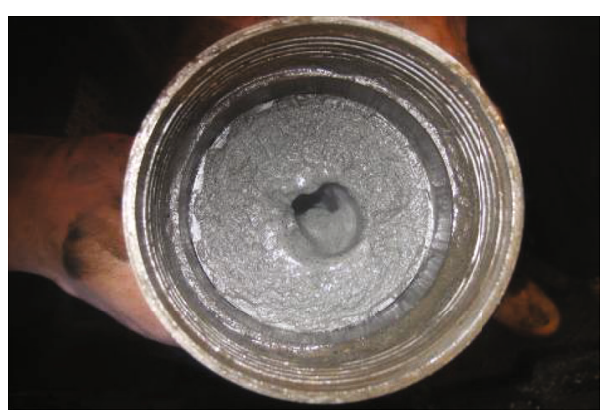

Figure 2: GZK1 pasted by loose backfill.

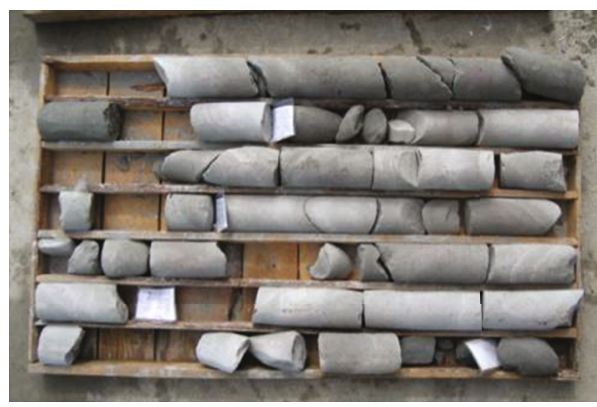

FIGURE 3: Backfill in GZK2 borehole.

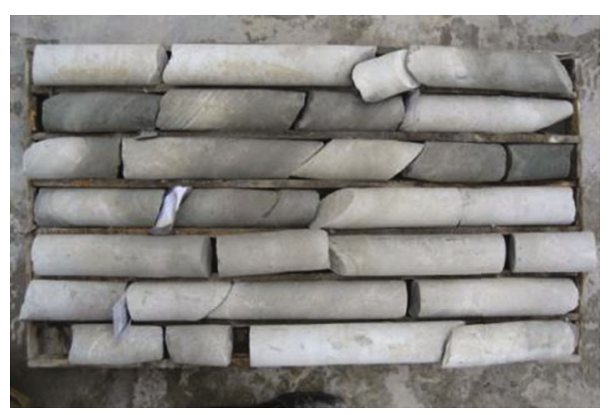

FIGURE 4: Backfill in GZK3 borehole.

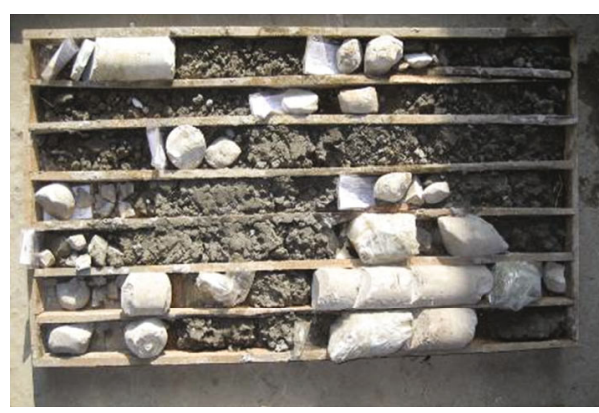

FIGURE 5: Backfill in GZK4 borehole.

in GZK1 because the bit was pasted by loose backfill. For GZK2, GZK3, and GZK4, drilling finished smoothly and cores are mostly long and short columnar while few are clastic and caky. The drilling stopped at the border of the backfill and wall rock. 
TABLE 2: Description of backfill.

\begin{tabular}{lcccc}
\hline Classification & Particle size & Colour & The strength & Cementing effect \\
\hline No.1 & Uniform & Offwhite & Better & Better \\
No.2 & Mainly made of fine particles & Dark grey & Better, light & Better \\
No.3 & Mainly made of coarse particles & Offwhite & Better, heavy & Better \\
No.4 & Mainly made of coarse particles & Dark grey & Worse & Worse \\
\hline
\end{tabular}

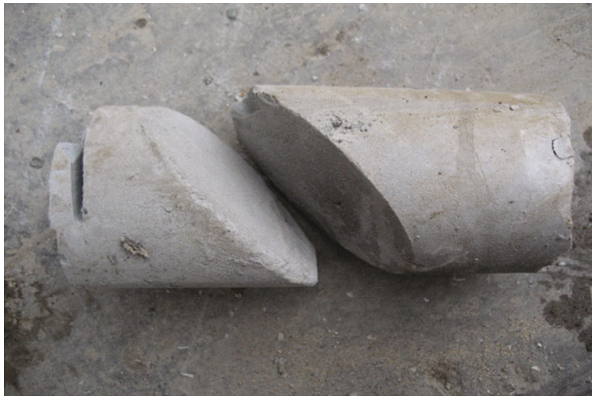

(a) Backfill made of uniform particles

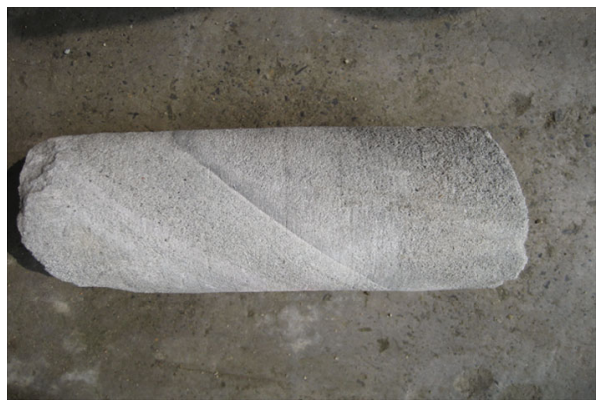

(c) Backfill made of coarse particles

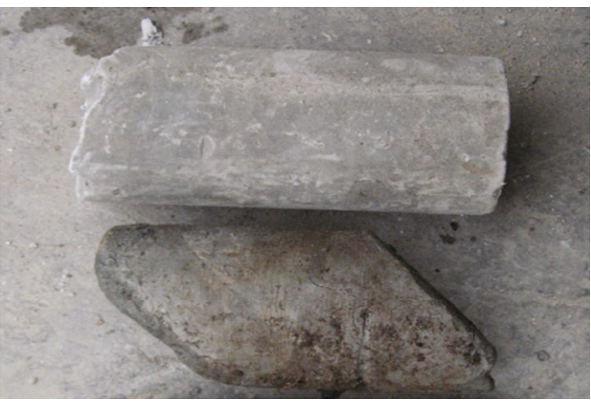

(b) Backfill made of fine particles

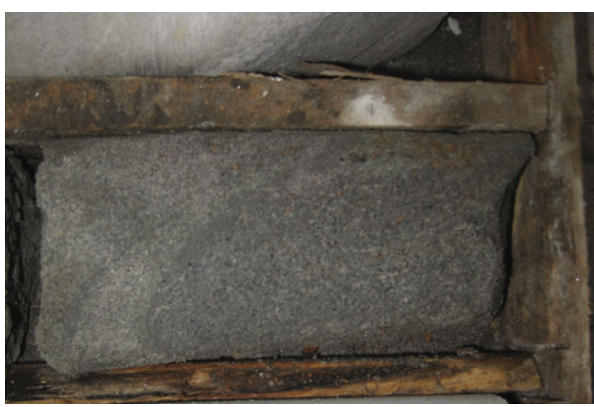

(d) Backfill made of coarse particles

Figure 6: Backfill made of different particles.

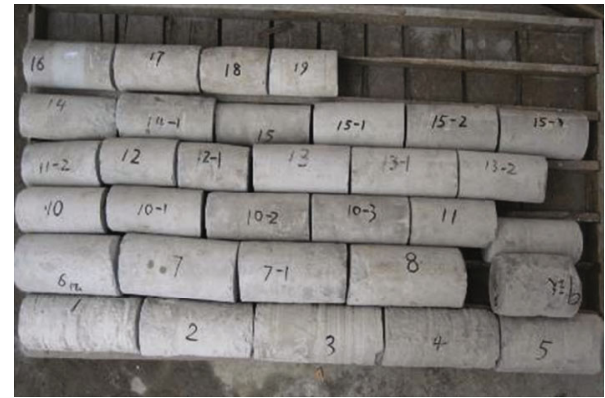

Figure 7: Samples for compression test.

3.2. Form of Backfill. After careful observation, the backfill is classified into four types including backfill made of uniform particles, backfill made of fine particles, backfill made of coarse particles with better cementing performance, and backfill made of coarse particles with poor cementing performance. The specific description of the backfill is listed in Table 2, and pictures are in Figure 6.

3.3. Sample Processing. According to the geotechnical test procedure, the backfill cores were cut by an electric saw and

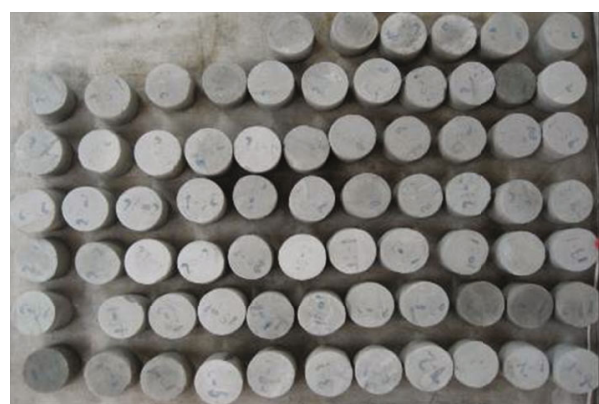

Figure 8: Samples for tensile test.

polished by a grinding wheel. The ratio of height and diameter of samples for compression and tensile tests is $2: 1$ and $0.5 \sim 1: 1$, respectively. The roughness of samples is less than or equal to $0.06 \mathrm{~mm}$ per $100 \mathrm{~mm}$, and nonperpendicularity of the bearing surface and the adjacent surface is less than or equal to $\pm 1^{\circ}$. The samples processed for compression and tensile tests are shown in Figures 7 and 8.

3.4. Mechanical Test. The uniaxial compressive and uniaxial tensile tests were done by building a material testing machine 

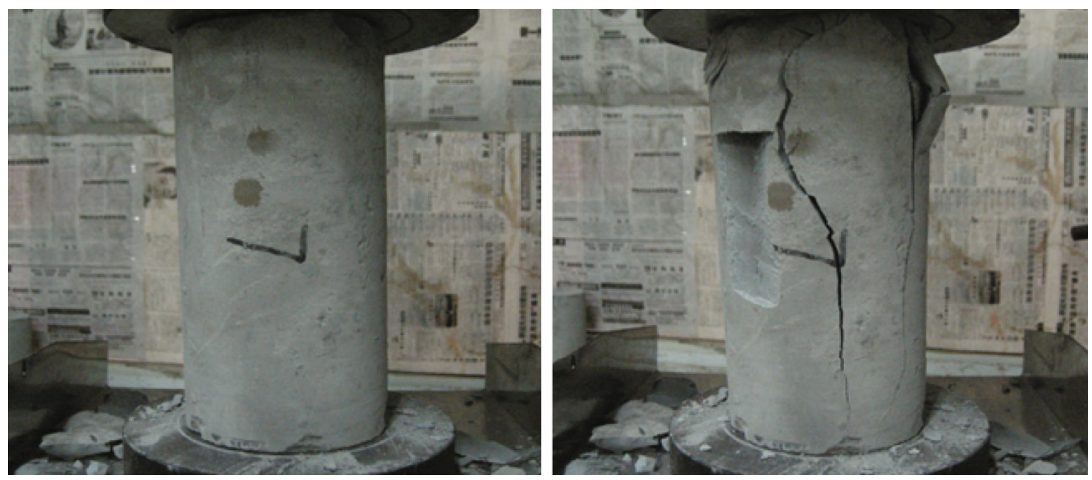

Figure 9: Uniaxial compressive strength test.
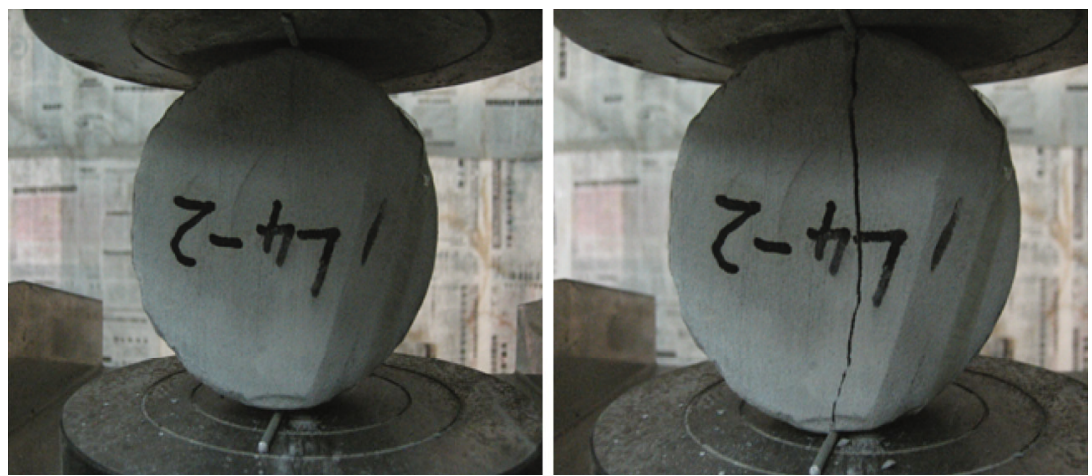

Figure 10: Uniaxial tensile strength test.

TABLE 3: Strength test data of backfill.

\begin{tabular}{lcccccc}
\hline \multirow{2}{*}{ No. } & \multirow{2}{*}{ Middle part } & \multicolumn{2}{c}{ Sample quantity } & \multicolumn{2}{c}{ Sampling density (no/m) } & \multicolumn{2}{c}{ Average strength (MPa) } \\
Compressive & Tensile \\
\hline GZK1 & -170 & 0 & 0 & 0 & 0 & 0 \\
GZK2 & -230 & 41 & 72 & 1.12 & 1.94 & 0 \\
GZK3 & -230 & 29 & 58 & 2.29 & 4.32 & 3.583 \\
GZK4 & -170 & 32 & 38 & 0.91 & 1.08 & 3.402 \\
In total & - & 102 & 168 & - & - & -2.928 \\
\hline
\end{tabular}

with a type of NYL-300. The test was finished in the following steps: set the measurement range on the basis of mechanical properties, hang the thallium, align the graduation line, crush the sample, turn off the oil feeding valve, then turn on the oil return valve, and record test data. Finally, dial back the follow-up pointer and clean the machine for the next test. The status of samples pre- and posttest is shown in Figures 9 and 10.

3.5. Results. The data including the total sampling number, sampling number per meter, uniaxial compressive strength, and uniaxial tensile strength of backfill cores from four drilling holes are shown in Table 3.

Four boreholes are drilled in the $17 \# \mathrm{R}$ stope. In GZK1, drilling stopped at $17.2 \mathrm{~m}$ and no core was obtained because of loose tailing and low strength of the backfill. There is almost no strength in some parts of the backfill.
In GZK2, drilling stopped at the loose part of the backfill with a depth of $44.06 \mathrm{~m}$ and vertical height of $25.27 \mathrm{~m} .41$ compressive samples were drilled with a sample density of $1.12 \mathrm{no} / \mathrm{m}$ and average compressive strength of $3.583 \mathrm{MPa}$ while 72 tensile samples were drilled with a sample density of $1.94 \mathrm{no} / \mathrm{m}$ and average tensile strength of $0.458 \mathrm{MPa}$.

In GZK3, drilling stopped at ore boundary with a depth of $21.08 \mathrm{~m}$ and vertical height of $15.42 \mathrm{~m}$. 29 compressive samples were drilled with a sample density of $2.29 \mathrm{no} / \mathrm{m}$ and average compressive strength of $3.402 \mathrm{MPa}$ while 58 tensile samples were drilled with a sample density of $4.32 \mathrm{no} / \mathrm{m}$ and average compressive strength of $0.524 \mathrm{MPa}$.

In GZK4, drilling stopped at the loose part with a depth of $65.33 \mathrm{~m}$ (bushing reached) and vertical height of $46.20 \mathrm{~m} .32$ compressive samples were drilled with a sample density of $0.91 \mathrm{no} / \mathrm{m}$ and average compressive strength of $2.928 \mathrm{MPa}$ while 38 tensile samples were drilled with a sample density of $1.08 \mathrm{no} / \mathrm{m}$ and average compressive strength of $0.328 \mathrm{MPa}$. 


\section{Discussion}

(1) As the test in $17 \# R$ shows, backfill features have uneven quality as a whole. The position where we got the core presents even filling, good setting and hardening in the bottom, and steady mechanical properties while segregation occurred influencing cementation of cement and finally led to strength difference

(2) In the upper part of the stope near the footwall (material feeding place), the core shows poor completeness, uneven quality, and little drilling cores which could be used for the test. Some cores in this position contain coarse particles without cement and little fine particles. With low or no strength, the backfill is chunky and granular with water contained. Some parts are flow-like and not set, almost showing no strength with uneven quality

(3) In the bottom of the stope near the hanging wall, the cores show good quality with even grain gradation, no local enrichment between coarse, and fine tailing and cement as well with low content of water

(4) The strength of backfill is high with a small quantity of round flakes and caky cores that formed in drilling by twisting the drilling pipe. As the status of the fracture surface of the backfill shows, the particle distribution is even, the cementation of particles is good, and no segregation occurs

\section{Conclusions}

(1) In Caolou Iron Mine, dewatering is done with a filter tube in the order of fixing bolts at the top of the drilling chamber linking road which is the opposite of the slurry feeding place, hanging filter tubes then traveling through the retaining wall of backfill in the bottom of the stope. As tailing settle fast, the dewatering will finish soon with two tubes. On the basis of practice, two or four tubes setting in a proper place are recommended for quick dewatering of tailing slurry

(2) The slurry concentration is of great importance to filling quality. As tests show, the slurry presents good fluidity with a slump of $28 \sim 25 \mathrm{~cm}$ when the concentration is in the range of $68 \sim 72 \%$, and water filtration decreases with the increase of concentration. So, high concentration is suggested for filling under the premise of good fluidity. Furthermore, the cleaning water should be kept away from the filling stope before and after filling to prevent filling materials in slurry from cementing decrease caused by the secondary dilution

(3) To ensure smooth mining in large mines, the backfill quality of the stope should be considered in selecting the mining method. The side controlled blasting is suggested to reduce the impact of the explosive shock wave on backfill. Sectional mining could be applied for safe and productive effective production

\section{Data Availability}

All data generated or analyzed during this study are included within this article.

\section{Conflicts of Interest}

The authors declare that they have no competing interests.

\section{Authors' Contributions}

D.Q. Deng wrote the main text of the manuscript. N. Jiang and Y. Duan collected and analyzed the data. All authors reviewed and commented on the manuscript.

\section{Acknowledgments}

The authors gratefully acknowledge support for this research from the National Natural Science Foundation of China (51764009), the Guizhou Province Science and Technology Support Plan Project (Grant No. [2018]2836), the Scientific Research Fund of Hunan Province Education Department (20A475), and the High-level Talent Gathering Project in Hunan Province (2019RS1059).

\section{References}

[1] M. Aubertin, L. Li, S. Arnoldi et al., "Interaction between backfill and rock mass in narrow stopes," Soil and Rock mechanics America, vol. 1, no. 2, pp. 1157-1164, 2003.

[2] S. Yin, L. Wang, A. Wu, E. Kabwe, X. Chen, and R. Yan, “Copper recycle from sulfide tailings using combined leaching of ammonia solution and alkaline bacteria," Journal of Cleaner Production, vol. 189, pp. 746-753, 2018.

[3] R. Cowling, "Twenty-five years of mine filling," in Developments and Directions.6th International Symposium on Mining with Backfill, pp. 3-10, Brisbane, 1998.

[4] S. Yin, L. Wang, X. Chen, and X. Wu, "Response of agglomeration and leaching behavior of copper oxides to chemical binders," International Journal of Minerals, Metallurgy and Materials, 2020.

[5] S. Yin, W. Chen, X. Chen, and L. Wang, "Bacterial-mediated recovery of copper from low-grade copper sulphide using acid-processed rice straw," Bioresource Technology, vol. 288, p. $121605,2019$.

[6] W. Blake, "Design considerations for seismic monitoring systems," in Rockbursts and Seismicity in Mines, pp. 79-82, SAIMM, Johannesburg, 1984.

[7] Y. L. Zhao, L. Y. Zhang, J. Liao, W. J. Wang, Q. Liu, and L. Tang, "Experimental study of fracture toughness and subcritical crack growth of three rocks under different environments," International Journal of Geomechanics, vol. 20, no. 8, article 04020128, 2020.

[8] A. J. Mendecki, Seismic Monitoring in Mines, Chapman and Hall Press, London, 1997.

[9] Y. Zhao, L. Zhang, W. Wang, Q. Liu, L. Tang, and G. Cheng, "Experimental study on shear behavior and a revised shear 
strength model for infilled rock joints," International Journal of Geomechanics, vol. 20, no. 9, article 04020141, 2020.

[10] Y. L. Zhao, C. S. Zhang, Y. X. Wang, and H. Lin, "Shear-related roughness classification and strength model of natural rock joint based on fuzzy comprehensive evaluation," International Journal of Rock Mechanics and Mining Sciences, vol. 137, no. 8, pp. 1-17, 2020.

[11] Y. Zhao, C. L. Wang, and J. Bi, "Analysis of fractured rock permeability evolution under unloading conditions by the model of elastoplastic contact between rough surfaces," Rock Mechanics and Rock Engineering, vol. 53, no. 12, pp. 57955808, 2020.

[12] A. G. Butler and G. van Aswegen, "Ground velocity relationships based on large sample of underground measurements in two South African mining regions," in Proceedings of the 3rd International Symposium on Rockbursts and Seismicity in Mines, Kingston, Ontario, Canada, 1993.

[13] S. Yin, Y. Shao, A. Wu, Z. Wang, and L. Yang, “Assessment of expansion and strength properties of sulfidic cemented paste backfill cored from deep underground stopes," Construction and Building Materials, vol. 230, article 116983, 2020.

[14] D. V. Ellis, "A review of some environmental issues affecting marine mining," Marine Georesources and Geotechnology, vol. 19, no. 1, pp. 51-63, 2001.

[15] K. Xia, C. Chen, Y. Zhou, X. Liu, Y. Zheng, and Y. Pan, “Catastrophe instability mechanism of the pillar-roof system in gypsum mines due to the influence of relative humidity," International Journal of Geomechanics, vol. 19, no. 4, article 06019004, 2019.

[16] W. H. Park, P. Packo, and T. Kundu, “Acoustic source localization in an anisotropic plate without knowing its material properties - a new approach," Ultrasonics, vol. 79, no. 1, pp. 9-17, 2017.

[17] T. Hajzargerbashi, T. Kundu, and S. Bland, "An improved algorithm for detecting point of impact in anisotropic inhomogeneous plates," Ultrasonics, vol. 51, no. 3, pp. 317-324, 2011.

[18] S. Yin, Y. Shao, A. Wu, S. Wang, and G. Li, "The effect of ferrous ions on hydraulic conductivity in fine tailings," Engineering Geology, vol. 260, article 105243, 2019.

[19] D. Ben, B. Brad, and M. Murray, "Constrained thermal expansion as a causal mechanism for in-situ pressure in cemented paste and hydraulic backfilled stopes," in International Symposium on Mining with Backfill, pp. 365-378, Australian Centre for Geomechanics, Perth, 2014.

[20] M. A. Khairul, J. Zanganeh, and B. Moghtaderi, "The composition, recycling and utilisation of Bayer red mud," Resources, Conservation and Recycling, vol. 141, pp. 483-498, 2019.

[21] S. K. Nath and S. Kumar, "Role of particle fineness on engineering properties and microstructure of fly ash derived geopolymer," Construction and Building Materials, vol. 233, p. 117294, 2020.

[22] Z. Li, J. Zhang, S. C. Li, Y. Gao, C. Liu, and Y. Qi, "Effect of different gypsums on the workability and mechanical properties of red mud-slag based grouting materials," Journal of Cleaner Production, vol. 245, article 118759, 2020.

[23] D. Wu, M. Fall, and S. J. Cai, "Coupling temperature, cement hydration and rheological behaviour of fresh cemented paste backfill," Minerals Engineering, vol. 42, pp. 76-87, 2013.

[24] J. Y. Petit, E. Wirquin, and K. H. Khayat, "Effect of temperature on the rheology of flowable mortars," Cement and Concrete Composites, vol. 32, no. 1, pp. 43-53, 2010.
[25] J. Y. Petit, K. H. Khayat, and E. Wirquin, "Coupled effect of time and temperature on variations of plastic viscosity of highly flowable mortar," Cement and Concrete Research, vol. 39, no. 3, pp. 165-170, 2009.

[26] L. Orejarena and M. Fall, "Artificial neural network based modeling of the coupled effect of sulphate and temperature on the strength of cemented paste backfill," Canadian Journal of Civil Engineering, vol. 38, no. 1, pp. 100-109, 2011.

[27] J. S. Mahlaba, E. P. Kearsley, R. A. Kruger, and P. C. Pretorius, "Evaluation of workability and strength development of fly ash pastes prepared with industrial brines rich in $\mathrm{SO} 4=$ and $\mathrm{Cl}^{-}$to expand brine utilisation," Minerals Engineering, vol. 24, no. 10, pp. 1077-1081, 2011.

[28] A. Kesimal, E. Yilmaz, and B. Ercikdi, "Environmental benefits by use of paste backfill technology for disposal of sulfide-bearing mine tailings," in Proceedings of the 4th International Scientific Conference-Modern Management of Mine Producing, Geology and Environmental Protection, pp. 431-440, Varna, Bulgaria, 2014.

[29] B. Ercikdi, H. Baki, and M. İzki, "Effect of desliming of sulphide-rich mill tailings on the long-term strength of cemented paste backfill," Journal of Environmental Management, vol. 115, pp. 5-13, 2013.

[30] E. Yilmaz, A. Kesimal, and B. Ercikdi, "Strength development of paste backfill samples at long term by using two different binders," in Proceedings of the 8th International Symposium on Mining with Backfill, pp. 281-285, China, September 2004.

[31] A. Kesimal, B. Ercikdi, and E. Yilmaz, "The effect of desliming by sedimentation on paste backfill performance," Minerals Engineering, vol. 16, no. 10, pp. 1009-1011, 2003.

[32] M. Fall and S. S. Samb, "Pore structure of cemented tailings materials under natural or accidental thermal loads," Materials Characterization, vol. 59, no. 5, pp. 598-605, 2008.

[33] X. X. Miao, "Principle of underground pressure control in fully-mechanized coal mining with solid filling and force analysis of mining and force analysis of mining support," Journal of China University of MiningぬTechnology, vol. 39, no. 6, pp. 795-801, 2010.

[34] M. Fall, M. Benzaazoua, and E. G. Saa, "Mix proportioning of underground cemented tailings backfill," Tunnelling and Underground Space Technology, vol. 23, no. 1, pp. 80-90, 2008.

[35] Q. Zhang, J. Zhang, Y. Huang, and F. Ju, "Backfilling technology and strata behaviors in fully mechanized coal mining working face," International Journal of Mining Science and Technology, vol. 22, no. 2, pp. 151-157, 2012.

[36] Z. He, K. Xie, and A. Zhou, "Research and practice of total tailings backfilling," The Chinese Journal of Nonferrous Metals, vol. 8, no. 4, pp. 739-744, 1998.

[37] X. X. Miao, J. X. Zhang, and M. M. Feng, "Waste-filling in fully-mechanized coal mining and its application," Journal of China University of Mining and Technology, vol. 18, no. 4, pp. 479-482, 2008.

[38] Z. Wang, "Effect of content and particle size distribution of coal gangue coarse aggregate on concrete performance," The Electronic Journal of Geotechnical Engineering, vol. 19, no. 5, pp. 9377-9388, 2014.

[39] Y. Baogui, D. Xueling, D. Peng, and Z. Kaifang, “The cemented filling technology using special filling roadway in Gob," The Electronic Journal of Geotechnical Engineering, vol. 20, no. 8, pp. 2087-2095, 2015.

[40] W.-q. Meng and Z.-q. Luo, "Research on key technologies of blasting design for complex boundary pillars at Donggua shan 
Mine," Nonferrous Metals (Mining Section), vol. 61, no. 3, pp. 55-58, 2009.

[41] G.-j. Zhou, Z.-w. Huang, and B.-s. Wang, "Study on largediameter longhole blasting of underground mining," Blasting, vol. 23, no. 4, pp. 25-29, 2006.

[42] Q. L. Zhang and X. M. Wang, "Performance of cemented coal gangue backfill," Journal of Central South University of Technology, vol. 14, no. 2, pp. 216-219, 2007.

[43] R. Currie, "Preparation of pastefill and its use at some Canadian mines," Australasian Institute of Mining and Metallurgy Publication Series, vol. 25, no. 1, pp. 325-330, 1998. 